\title{
PENERAPAN STRATEGI QUICK ON THE DRAW UNTUK MENINGKATKAN AKTIVITAS DAN HASIL BELAJAR SISWA DI KELAS X MIA1 SMA AL-FALAH KOTA JAMBI
}

Sydik Dwi Setianto ${ }^{1}$, Menza Hendri ${ }^{2}$, dan Darmaji ${ }^{3}$

1,2,3Program Studi Pendidikan Fisika FKIP Universitas Jambi, Jambi, Indonesia

Corresponding author email: dwisydik@yahoo.com

\section{Info Artikel}

Diterima:

22 Mei 2019

Disetujui:

19 Mei 2020

Dipublikasikan:

30 Juni 2020

\begin{abstract}
Abstrak:
Penelitian ini bertujuan untuk meningkatkan aktivitas dan hasil belajar siswa. Metode penelitian ini adalah penelitian tindakan kelas. Penelitian ini merupakan penelitian tindakan kelas yang terdiri dari tiga siklus. Subjek penelitian ini siswa kelas X MIA1 Sma Al-Falah. Instrument penelitian ini menggunakan lembar observasi dan test. Hasil observasi dianalisis secara deskriptif kualitatif, sedangkan hasil tes akan dianalisis secara statistic deskriptif. Peningkatan aktivitas siswa terlihat dari ratarata persentase aktivitas siswa pada siklus I adalah 50,20\%, meningkat pada siklus II menjadi $67,70 \%$, dan meningkat pada siklus III menjadi $88,85 \%$. Sedangkan hasil belajar siklus I 67,50 meningkat pada siklus II menjadi 72,50 kemudian meningkat pada siklus III menjadi 77,50. Hasil penelitian ini menunjukkan adanya peningkatan aktivitas dan hasil belajar fisika siswa pada tiap siklus. Dari hasil penelitian dapat disimpulkan bahwa penerapan strategi pembelajaran aktif tipe quick on the draw dapat meningkatkan aktivitas dan hasil belajar fisika pada materi besaran dan satuan di kelas X MIA1 Sma Al-Falah Kota Jambi.
\end{abstract}

Kata kunci: Quick on the draw, aktivitas, hasil belajar

\begin{abstract}
:
This study aims to increase student activity and learning outcomes. This research method is classroom action research. This research is a classroom action research which consists of three cycles. The subjects of this study were students of class X MIA1 SMA Al-Falah. The research instrument used the observation sheet and test. The results of observations were analyzed descriptively qualitatively, while the test results were analyzed using descriptive statistics. The increase in student activity can be seen from the average percentage of student activity in the first cycle is 50.20\%, an increase in the second cycle to $67.70 \%$, and an increase in the third cycle to $88.85 \%$. While the learning outcomes of the first cycle 67.50 increased in the second cycle to 72.50 and then increased in the third cycle to 77.50. The results of this study indicate an increase in activity and student learning outcomes of physics in each cycle. From the results of the study it can be concluded that the application of active learning strategies type quick on the draw can increase activity and physics learning outcomes in the material quantities and units in class X MIA1 SMA Al-Falah Jambi City.
\end{abstract}

Keywords: Quick on the draw, learning activity, learnin outcomes 


\section{Pendahuluan}

Mata pelajaran Fisika mempunyai peranan penting dalam menunjang ilmu pengetahuan dan teknologi. Fisika merupakan salah satu mata pelajaran yang membutuhkan pemahaman konsep dan aplikasi dalam kehidupan sehari-hari. Mata pelajaran Fisika telah diperkenalkan kepada siswa sejak sekolah dasar yang dikenal dengan pelajaran IPA hingga ke perguruan tinggi. Akan tetapi, pada kenyataannya pelajaran Fisika kurang diminati siswa pada umumnya, karena dianggap sulit dan membosankan, sehingga proses pembelajaran Fisika tidak berjalan seperti yang diharapkan dan hasil belajar Fisika siswa tidak maksimal.

Berdasarkan hasil wawancara di SMA Al- Falah Jambi dengan guru fisika diperoleh informasi bahwa selama proses pembelajaran Fisika, siswa kurang aktif dan mengalami kesulitan dalam memahami konsep. Pada kegiatan pembelajaran siswa belum mampu belajar mandiri dan masih menunggu penjelasan dari guru. Hal ini berdampak negatif terhadap hasil belajar yang diperoleh siswa. Hasil belajar Fisika kelas $\mathrm{X}_{1}$ IPA pada ujian mid semester belum memuaskan. Hal tersebut dapat dilihat dari rata-rata nilai Fisika yang hanya 65,14. Nilai ini masih berada di bawah kriteria ketuntasan minimal (KKM) yang ditetapkan sekolah yaitu 75 .

Selama ini proses pembelajaran yang berlangsung di SMA Al- Falah Jambi cenderung terpusat pada guru. Guru menjelaskan materi pelajaran, memberikan contoh soal, siswa mencatat, mengerjakan latihan dan diakhir pelajaran diberikan pekerjaan rumah. Guru kurang memotivasi siwa untuk terlibat aktif dalam proses pembelajaran. Hal ini mengakibatkan rendahnya aktivitas belajar siswa dan membuat siswa jenuh karena sistem belajarnya selalu sama. Jika siswa jenuh dalam kegiatan pembelajaran, maka hasil belajarnya pun tidak maksimal.

Oleh karena itu, guru dituntut untuk menciptakan pembelajaran yang dapat meningkatkan keaktifan siswa dalam belajar, sehingga siswa termotivasi untuk belajar Fisika dan dapat meningkatkan hasil belajar siswa. Salah satu cara untuk mengaktifkan siswa dalam belajar adalah dengan menerapkan strategi pembelajaran aktif. Pembelajaran aktif mendorong siswa untuk berpatisipasi dalam semua proses pembelajaran. Salah satu strategi pembelajaran yang dapat mengaktifkan dan meningkatkan hasil belajar Fisika siswa yaitu strategi pembelajaran aktif tipe Quick On The Draw.

Menurut Pamilih (2014) mengemukakan hasil penelitiannya bahwa penerapan starategi pembelajaran dengan tipe Quick On The Draw yang diterapkan di kelas V SDN 01 Wonolopo dapat meningkatkan hasil belajar IPS siswa. Hal ini bisa dilihat dari jumlah ketuntasan minimal siswa yang mengikuti pembelajaran pada siklus I, II dan III. Pada siklus I nilai rata-rata hasil belajar IPS siswa mencapai 69 dengan persentase ketuntasan 53\%, pada siklus II miningkat menjadi 83 dengan persentase ketuntasan $77 \%$ dan pada siklus III meningkat lagi menjadi 84 dengan persentase ketuntasan 97\%. Hal ini bisa dilihat dari rata-rata hasil belajar siswa pada siklus III dengan jumlah siswa yang sudah mencapai KKM sebanyak $97 \%$

Menurut Surmayani (2013) mengemukakan hasil penelitiannya bahwa penerapan starategi pembelajaran dengan tipe Quick On The Draw yang diterapkan di kelas IV SDN 007 kampung baru kabupaten kuantan singingi dapat meningkatkan hasil belajar IPA siswa. Hal ini bisa dilihat dari jumlah ketuntasan minimal siswa yang mengikuti pembelajaran pada siklus I, II dan III. Pada siklus I nilai rata-rata hasil belajar IPA siswa yang mencapai KKM 8 siswa dengan persentase ketuntasan 44,44\%, pada siklus II miningkat menjadi 11 siswa dengan persentase ketuntasan $61,11 \%$ dan pada siklus III meningkat lagi menjadi 16 siswa dengan persentase ketuntasan 88,89\%. Hal ini bisa dilihat dari rata-rata hasil belajar siswa pada siklus III dengan jumlah siswa yang sudah mencapai KKM sebanyak 16 siswa dengan persentase ketuntasan 88,89\%

Menurut Ginting (2008) strategi pembelajaran aktif tipe Quick On The Draw merupakan strategi pembelajaran yang mengutamakan kerja sama dan kecepatan. Di dalamnya terdapat kecepatan antar kelompok yang tidak begitu rumit. Tujuannya adalah menjadi kelompok pertama yang menyelesaikan satu set pertanyaan. Penerapan strategi ini juga mendorong kerja sama dalam kelompok, mengajak siswa untuk dapat belajar mandiri, membiasakan siswa belajar berdasarkan sumber bukan guru. Strategi pembelajaran ini sesuai bagi siswa dengan gaya belajar kinestetik yang tidak dapat duduk 
diam selama lebih dari dua menit. Penerapan strategi pembelajaran ini akan membuat siswa tidak bosan dan mendorong siswa bersemangat dalam belajar. Tantangan yang diberikan dalam strategi pembelajaran ini akan mampu meningkatkan keaktifan dan hasil belajar Fisika siswa. Silberman (2006) menyatakan strategi pembelajaran aktif ini bisa disamakan dengan ujian open book. Siswa bekerja sama dalam kelompok mencari informasi untuk menjawab pertanyaan yang diajukan. Tantangan yang diberikan dalam strategi pembelajaran ini dapat meningkatkan keaktifan siswa dalam belajar

Tujuan dilaksanakan penelitian ini adalah untuk mengetahui apakah setelah menerapkan strategi pembelajaran aktif tipe Quick On The Draw bisa meningkatkan aktivitas dan hasil belajar Fisika pada materi besaran dan satuan di kelas X MIA1 SMA Al-Falah Kota Jambi. Kegunaan penelitian ini untuk meningkatkan aktivitas dan hasil belajar fisika siswa dalam proses pembelajaran.

\section{Metode Penelitian}

Jenis penelitian ini adalah Penelitian Tindakan Kelas (Classroom Action Research). Penelitian ini dilaksanakan di kelas X MIA1 SMA Al- Falah Jambi pada semester ganjil tahun ajaran 2017/2018. Tempat yang digunakan untuk penelitian adalah SMA Al-Falah Jambi. Dalam penelitian ini yang menjadi subjek penelitian adalah siswa kelas X MIA1 SMA Al- Falah Jambi pada semester ganjil tahun ajaran 2017/2018 semester I yang terdiri dari 30 siswa. Penelitian ini dilaksanakan dalam tiga siklus yang terdiri dari siklus I, siklus II dan siklus III. Pada tiap siklus memiliki tahapan-tahapan tertentu sesuai dengan tahapan dalam tindakan kelas. Menurut Arikunto (2012) secara garis besar terdapat 4 tahapan yang lazim dilalui, yaitu

\section{Perencanaan atau persiapan tindakan (Planning)}

Pada tahap ini peneliti membuat rencana pembelajaran, mempersiapkan alat-alat pendukung yang diperlukan di kelas sesuai dengan rencana pembelajaran, membuat lembar observasi aktivitas siswa, membuat lembar observasi pelaksanaan pembelajaran, menyiapkan lembar kerja siswa (LKS) dan merancang alat evaluasi berupa soal tes dan kunci jawaban

\section{Pelaksanaan tindakan (Acting)}

Dalam pelaksanaan tindakan ini, kegiatan pembelajaran dilaksanakan sesuai dengan rencana pembelajaran yang telah disiapkan pada persiapan tindakan.

\section{Observasi (pengamatan) dan evaluasi}

Pengamatan terhadap pembelajaran menggunakan lembar observasi yang berupa lembar observasi aktivitas siswa dan lembar observasi pelaksanaan pembelajaran sementara evaluasi dilaksanakan setelah proses kegiatan belajar mengajar pada setiap akhir siklus dengan memberikan tes akhir.

\section{Analisis dan refleksi (Reflecting)}

Data yang telah diperoleh akan dianalisis dengan menggunakan perhitungan dan penilaian pada masing-masing siklus. Dari hasil analisis dan refleksi akan diketahui apakah tindakan yang dilakukan dapat memecahkan permasalahan yang ada. Jika permasalahan tersebut belum terselesaikan maka akan diadakan perbaikan (revisi) pada siklus berikutnya.

Jenis data yang diambil dalam penelitian ini adalah:

1. Data Kualitatif yaitu data tentang aktivitas siwa dan pelaksanaan pembelajaran dalam proses belajar mengajar.

2. Data Kuantitatif yaitu data tentang hasil belajar siswa setiap akhir siklus

Intrumen Penelitian

Lembar observasi siswa digunakan sebagai instrumen untuk mengetahui keaktifan siswa dalam proses pembelajaran. Lembar observasi pelaksanaan pembelajaran ini digunakan sebagai instrumen untuk mengetahui kemampuan guru dalam menerapkan strategi pembelajaran Quick On The Draw pada proses pembelajaran. Data hasil belajar siswa diambil melalui tes hasil belajar yang dilaksanakan setiap akhir siklus pembelajaran. Sebelum soal tes digunakan dalam penelitian perlu dilakukan uji coba dan analisa untuk memperoleh validitas, tingkat kesukaran tiap soal, daya pembeda, dan reliabilitas yang memenuhi kriteria tertentu 
Teknik pengumpulan Data

1. Data hasil belajar siswa diambil melalui tes (ulangan formatif) yang diadakan di setiap akhir siklus pembelajaran.

2. Data aktivitas belajar siswa diambil dari lembar observasi yang dilakukan oleh pengamat saat melaksanakan penelitian.

3. Data kegiatan guru diambil dari lembar observasi yang dilakukan oleh pengamat saat melaksanakan penelitian.

4. Dokumentasi pelaksanaan pembelajaran berupa foto dan video.

Teknik Analisis Data

Untuk menganalisis data yang diperoleh dalam penelitian digunakan beberapa teknik analisis data sebagai berikut:

1. Data Kuantitatif

Data kuantitatif yang digunakan untuk mengamati penilaian hasil belajar siswa pada masingmasing siklus digunakan rumus yang dikemukakan oleh Purwanto (2008), dengan menggunakan persamaan berikut:

Keterangan:

$$
S=\Sigma\left(R-\frac{W}{n-1}\right) x W t
$$

$S=$ Skor

$R=$ Jumlah jawaban yang benar

$W=$ Jumlah jawaban yang salah

$W t=$ Bobot

$n=$ Jumlah option

Nilai rata-rata kelas dihitung dengan menggunakan persamaan yang dikemukakan oleh Sudjana (1992), sebagai berikut:

$$
\bar{x}=\frac{\sum N a}{N}
$$

Keterangan:

$\bar{x}=$ Nilai rata-rata

$\mathrm{Na}=$ Jumlah nilai ulangan siswa

$N$ = Jumlah siswa keseluruhan

Untuk menghitung persentase tingkat keberhasilan belajar digunakan persamaan yang dikemukakan oleh Arikunto (2013) sebagai berikut:

$$
\text { nilai }=\frac{\text { skor mentah }}{\text { skor maksimum }} \times 100 \%
$$

\section{Data Kualitatif}

Data kualitatif yang digunakan untuk mengamati aktivitas siwa selama proses pembelajaran berlangsung. Analisis kualitatif untuk data hasil observasi mengenai keaktifan belajar siswa dihitung dengan rumus:

$$
A=\frac{N_{a}}{N} \times 100 \%
$$


Keterangan:

$A=$ Aktivitas siswa

$N_{\alpha}=$ Jumlah siswa yang aktif

$N=$ Jumlah siswa keseluruhan

Dimana perhitungan penilaiannya sebgai berikut:

Tabel 1. Perhitungan Penilaian

\begin{tabular}{cc}
\hline Rentang & Kategori \\
\hline $0-20$ & Tidak Aktif \\
$21-40$ & Kurang Aktif \\
$41-60$ & Cukup Aktif \\
$61-80$ & Aktif \\
$81-100$ & Sangat Aktif \\
\hline
\end{tabular}

Angka rata-rata aktivitas yang diperoleh kemudian di cocokkan dengan kategori. Angkaangka tersebut dapat dijadikan tolak ukur yang dapat menunjukkan kualitas aktivitas siwa selama proses pembelajaran berlangsung.

\section{Hasil Penelitian dan Pembahasan}

Berdasarkan hasil penelitian yang dilaksanakan di kelas X MIA1 SMA Al-Falah Kota Jambi digunakan Kurikulum 2013. Penelitian pada siklus I,II, dan III dilakukan dengan 2 kali pertemuan, dimana pada akhir siklus dilakukan tes formatif untuk memperoleh hasil pengetahuan siswa. Berdasarkan hasil penelitian yang di Sma Al-Falah kota jambi rincian mengenai peningkatan hasil belajar siswa pada aspek kognitif yang diperoleh dari penerapan strategi pembelajaran aktif tipe quick on the draw dapat dilihat pada Tabel 1.

Tabel 2. Peningkatan Hasil Belajar Siswa

\begin{tabular}{cccc}
\hline Variabel yang diamati & Siklus & Siklus & Siklus \\
& 1 & II & III \\
\hline Nilai rata-rata siswa & 67,50 & 72,50 & 77,50 \\
Banyaknya siswa yang berhasil & 11 & 18 & 23 \\
Persentase siswa yang berhasil & 36,67 & 60,00 & 76,66 \\
\hline
\end{tabular}

Dari Tabel 2. Dapat dilihat bahwa nilai rata-rata penguasaan materi meningkat dari siklus I, II dan pada siklus III. Pada siklus I nilai rata-rata 67,50 belum mencapai target KKM yang ingin dicapai oleh karena itu dilanjutkan lagi siklus II. Pada siklus II nilai rata-rata yang didapatkan adalah 72,50 juga belum mencapai KKM yang ingin dicapai dan dilanjutkan lagi siklus III untuk mencapai target KKM tersebut. Pada siklus III nilai yang didapatkan 77,50 dan telah mencapai target KKM yang ditentukan pada indikator keberhasilan. Oleh karena itu, penelitian dihentikan pada siklus III. Peningkatan aktivitas dan hasil belajar fisika dapat dilihat pada table 2.

Tabel 3. Peningkatan aktivitas dan hasil belajar fisika_siswa tiap siklus

\begin{tabular}{clc}
\hline Siklus & $\begin{array}{l}\text { Rata-rata } \% \\
\text { Aktivitas } \\
\text { Siswa }\end{array}$ & $\begin{array}{c}\text { Rata-rata hasil } \\
\text { Belajar fisika siswa }\end{array}$ \\
\hline I & 50,20 & 67,50 \\
II & 67,70 & 72,50 \\
III & 88,85 & 77,50 \\
\hline
\end{tabular}


Dari table 2. Dapat dilihat bahwa pelaksanaan pembelajaran menggunakan strategi pembelajaran aktif tipe Quick On The Draw dapat meningkatkan aktivitas dan hasil belajar fisika siswa pada materi besaran dan satuan di kelas X MIA1 Sma Al-Falah Kota Jambi. Untuk melihat hasil peningkatannya juga dapat dilihat pada Grafik gambar 1 .

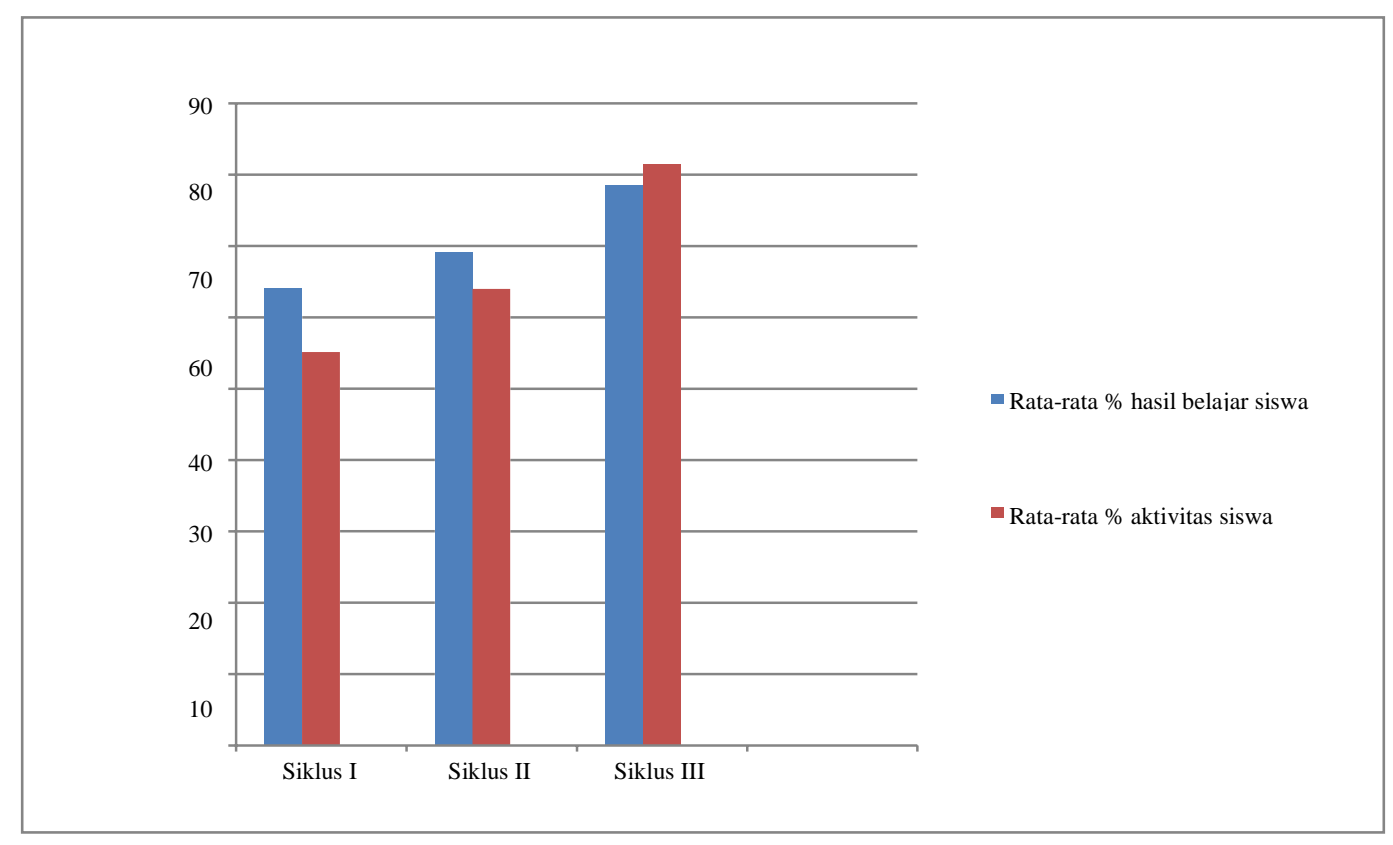

Gambar 1. Peningkatan hasil belajar dan aktivitas belajar siswa

Pada Gambar 1. di atas dapat dilihat dengan jelas bahwa telah terjadi peningkatan yang signifikan pada hasil belajar siswa dan aktivitas belajar siswa setiap siklusnya. Dengan meningkatnya aktivitas siswa pada grafik di atas maka hasil belajar siswa pun turut meningkat. Pengamatan yang dilakukan peneliti setelah dilakukan tindakan, dengan penerapan pembelajaran aktif tipe Quick On The Draw membawa perubahan perilaku siswa kea rah yang lebih baik. Pembelajaran sudah terpusat pada siswa, kegiatan pembelajaran sudah berjalan lancar dan hasilnya sudah mengalami peningkatan. Peneliti tentang peningkatan keaktifan belajar matematika telah dilakukan oleh beberapa peneliti terdahulu, salah satunya oleh Atmah (2011) menunjukkan bahwa pembelajaran IPA dengan strategi pembelajaran Quick On The Draw dapat meningkatkan respon siswa, dan hasil pembelajaran. Hal ini dibuktikan dengan meningkatnya respon siswa dan hasil belajar. Jadi perbedaan penelitian yang dilakukan Atmah dengan peneliti adalah terletak pada respon siswa, tinjauan dan nilai KKM yang digunakan. Persamaanya adalah salah satu fokus yang digunakan yaitu peningkatan hasil belajar IPA. Hasil penelitian Khairil Ilmi (2011) menunjukkan bahwa dengan menggunakan strategi tipe Quick on the Draw aktifitas siswa dapat dikualifikasikan aktif dan hasil belajar matematika siswa dalam pembelajaran pokok bahasan himpunan dengan menggunakan strategi tipe Quick on the Draw meningkat dari kualifikasi cukup pada siklus I menjadi kualifikasi baik pada siklus II. Jadi persamaan penelitian yang dilakukan Khairil Ilmi dengan peneliti adalah sama-sama menggunakan tipe quick on the draw. Jadi perbedaan penelitian yang dilakukan Khairil Ilmi dengan peneliti adalah terletak pada jenjang pendidikan, mata pelajaran, dan lokasi penelitian. Khairil Ilmi menerapkan tipe quick on the draw pada siswa kelas VII SMPN 1 Belawang untuk meningkatkan hasil belajar matematika pada pokok bahasan himpunan, sedangkan peneliti menerapkan strategi tipe quick on the draw pada jenjang SMA kelas X MIA 1 SMA Al-Falah Kota Jambi untuk mata pelajaran Fisika materi besaran dan satuan.

Sesuai yang diungkapkan Dimyati dan Mujiono (2006) menyatakan bahwa strategi Quick on the Draw menekankan aktivitas siswa untuk melakukan kecepatan menyelesaikan soal di dalam kelompok dengan adanya interaksi antara anggota dalam suatu kelompok maka siswa dapat menyelesaikan tugas secara bersama-sama. Haisyam Zaini (2008) menyatakan bahwa siswa yang aktif dalam belajar, pengetahuan yang diterima siswa akan lebih diingat sehingga prestasi belajar menjadi lebih baik. 
Suryo Subroto (2002) menyatakan pada tahap penyelesaian soal siswa melakukan kerjasama yang dilakukan oleh kelompok atau tim lebih ringan dan efektif dari pada kerjasama individual.

\section{Simpulan}

Dari analisa data penelitian yang telah dilakukan diperoleh peningkatan nilai rata-rata persentase aktivitas dan hasil belajar siswa. Pada siklus I, rata-rata persentase aktivitas siswa adalah $50,20 \%$ dan nilai rata-rata belajar 67,50 dengan jumlah siswa yang berhasil sebanyak 11 orang. Kemudian mengalami peningkatan pada siklus II yaitu, untuk rata-rata persentase aktivitas siswa meningkat menjadi 67,70 \% dan nilai rata-rata hasil belajar 72,50 dengan jumlah yang berhasil 18 orang. Selanjutnya pada siklus III mengalami peningkatan lagi yaitu, untuk aktivitas siswa meningkat menjadi 88,85\% dan nilai rata-rata hasil belajar 77,50 dengan jumlah siswa yang berhasil 23 orang. Berdasarkan hasil penelitian yang diperoleh, dapat disimpulkan bahwa pelaksaan pembelajaran dengan menggunakan Strategi Pembelajaran Aktif Tipe Quick On The Draw pada materi besaran dan satuan dapat meningkatkan aktivitas dan hasil belajar siswa di kelas X MIA1 Sma Al-Falah Kota Jambi.

\section{Referensi}

Aiumatul Hidayah. 2016. Efektivitas model pembelajaran kooperatif tipe quick on the draw terhadap kemampuan berpikir kreatif matematis pada materi bangun ruang kelas VIII. Jurnal Ums. 3 (1): 39-47.

Agung Saputra. 2018. Peningkatan kemampuan komunikasi matematis siswa dengan pembelajaran kooperatif tipe quick on the draw. Jurnal matematika ilmiah STKIP muhammadiyah kuningan. 4 (2): 25-30.

Andri Wahyu. 2011. Penerapan pembelajaran kooperatif tipe quick on the draw untuk meningkatkan keaktifan dan hasil belajar fisika. Jurnal UMS 3 (2): 1-15.

Andi Maulana. 2018. Pengaruh penerapan strategi pembelajaran quick on the draw terhadap motivasi dan hasil belajar siswa SMPN 3 Palangga. Jurnal Biotek 6 (6): 43-52.

Anderson, Lorin W \& Krathwohl, David R. 2010. Kerangka Landasan Untuk Pembelajaran, Pengajaran, dan Asesmen. Yogyakarta: Pustaka Pelajar.

Arikunto, Suharsimi, Suhardjono \& Supardi. 2010. Penelitian Tindakan Kelas. Jakarta: PT. Bumi Aksara.

Arikunto, Suharsimi. 2013. Dasar-dasar Evaluasi Pendidikan. Jakarta: PT. Bumi Aksara.

Atmah. 2011. Penerapan strategi quick on the draw dalam pembelajaran IPA SMP pada materi system dalam kehidupan manusia. Jurnal Inovasi Pendidikan 2 (1): 13-18.

Dian Ramadhani. 2017. Penerapan pembelajaran kooperatif dengan teknik quick on the draw untuk meningkatkan hasil belajar matematika siswa kelas VII SMPN 32 Pekanbaru. Jurnal Aksiomatik 1 (2): 17-26.

Dimyati dan Mudjiono. 2006. Belajar dan Pembelajaran. Rineka cipta. Jakarta.

Fitriansyah . 2009. Upaya meningkatkan hasil belajar matematika siswa SMPN 3 Bellawang melalui strategi pembelajaran quick on the draw. Jurnal pendidikan matematika 1 (2): 16-21.

Ginnis, Paul. 2008. Trik \& Taktik Mengajar: Strategi Meningkatkan Pencapaian Pengajaran di Kelas. Jakarta: PT. Indeks.

Hamalik, Oemar. 2013. Kurikulum dan Pembelajaran. Jakarta: PT. Bumi Aksara.

Hamalik, Oemar. 2013. Proses Belajar Mengajar. Jakarta: PT. Bumi Aksara. 
Hardika lestiyaningsih. 2012. Penerapan pembelajaran quick on the draw untuk meningkatkan hasil belajar MTK pada sub pokok bahasan aritmetika sosial siswa kelas VII F SMPN 10 Jember. Jurnal pendidikan matematika 3 (2): 11-19.

Ilmi, Khairil. 2011. Penggunaan strategi pembelajaran tipe quick on the draw untuk meningkatkan hasil belajar matematika pokok bahasan himpunan siswa kelas VII A SMPN 1 Belawang Kabupaten Batola Tahun Pelajaran 2010/2011. Banjarmasin: STKIP-PGRI.

Kanginan, Marthen. 2013. Fisika Untuk SMA/MA Kelas X. Jakarta: Erlangga.

Lastri. 2013. Meningkatkan hasil belajar siswa melalui strategi quick on the draw pada mata pelajaran IPA kelas IV SDN 07 kampung baru kabupaten kuantan singigi. Riau. UIN Sultan Syarif Kasim RIAU.

Marta Malindo. 2015. Penerapan strategi pembelajaran aktif quick on the draw untuk meningkatkan prestasi belajar siswa pada pokok bahasan larutan asam basa dikelas XI IPA SMA 1 kandis. Jurnal kimia 4 (3): 11-21.

Melia, Roza. 2016. Pengaruh model pembelajaran kooperatif melalui teknik quick on the draw terhadap kemampuan matematis siswa kelas VII SMPN 3 Talamau. Jurnal Ilmiah teknologi pendidikan. 1 (1): 1-11.

Nurain, Suryadinata. 2015. Penerapan pembelajaran quick on the draw terhadap kemampuan berpikir kreatif matematis siswa SMP. Jurnal Edumatica.5 (2): 9-18.

Purwanto. 2014. Evaluasi hasil belajar. Yogyakarta: Pustaka Pelajar.

Ratna. 2014. Penerapan strategi pembelajaran quick on the draw untuk meningkatkan hasil belajar IPS di kelas V SDN 01 Wonolopo. Surakarta. Universitas Muhammadiyah Surakarta.

Rosmaini. 2011. Penerapan model pembelajaran kooperatif dengan strategi quick on the draw untuk meningkatkan sikap ilmiah dan hasil belajar biologi siswa kelas XI IPA SMAN 2 Kuantah Hilir. Jurnal Biogenesis 9 (1): 51-65.

Sanjaya, Wina. 2009. Straategi Pembelajaran Berorientasi Standar Proses Pendidikan. Jakarta: Kencana.

Silberman. 2006. 101 Cara Belajar Siswa Aktif. Bandung: Nusamedia.

Slameto. 2013. Belajar dan Faktor-Faktor Yang Mempengaruhinya. Jakarta: Rineka Jaya.

Suryo Subroto. 2002. Proses belajar mengajar di sekolah. Jakarta: Rineka Cipta.

Syah, Muhibbin. 2013. Psikologi Pendidikan Dengan Pendekatan Baru. Bandung: PT. Remaja Rosdakarya.

Tampubolon, Saur. 2014. Penelitian Tindakan Kelas sebagai Pengembangan Profesi Pendidik dan Keilmuan. Jakarta: Erlangga.

Ukhti Nusyifa. 2018. Pengaruh penerapan teknik quick on the draw terhadap motivasi dan hasil belajar MTK siswa kelas IX. Jurnal STKIP PGRI sumatera barat.4 (1): 81-86.

Wena, Made. 2012. Strategi Pembelajarn Inovatif Kontemporer: Suatu Tinjauan Konseptual Operasional. Jakarta: PT. Bumi Aksara.

Yamin, Martinis. 2007. Kiat Membelajarkan Siswa. Jakarta: Gaung Persada Press.

Zaini, Hisyam, Munthe, Bermawy \& Aryani, Sekar Ayu. 2008. Strategi Pembelajaran Aktif. Yogyakarta: Pustaka Insan Madani. 
Zarkasi, M. Firdaus. 2009. Belajar Cepat Dengan Diskusi. Surabaya: Penerbit IndahPembelajaran. Jakarta: PT. Bumi Aksara. 